\title{
Miranda
}

Revue pluridisciplinaire du monde anglophone /

Multidisciplinary peer-reviewed journal on the English-

speaking world

$10 \mid 2014$

Images on the Move: Circulations and Transfers in film

\section{Adelene Buckland, Novel Science: Fiction and the Invention of Nineteenth-Century Geology}

Laurence Talairach-Vielmas

URL: http://journals.openedition.org/miranda/6409

DOI: $10.4000 /$ miranda.6409

ISSN: 2108-6559

Publisher

Université Toulouse - Jean Jaurès

Electronic reference

Laurence Talairach-Vielmas, "Adelene Buckland, Novel Science: Fiction and the Invention of Nineteenth-

Century Geology", Miranda [Online], 10 | 2014, Online since 23 February 2015, connection on 16

February 2021. URL: http://journals.openedition.org/miranda/6409 ; DOI: https://doi.org/10.4000/ miranda.6409

This text was automatically generated on 16 February 2021.

\section{(c) $(1)$}

Miranda is licensed under a Creative Commons Attribution-NonCommercial-NoDerivatives 4.0 International License. 


\title{
Adelene Buckland, Novel Science: Fiction and the Invention of Nineteenth- Century Geology
}

\author{
Laurence Talairach-Vielmas
}

\section{REFERENCES}

Adelene Buckland, Novel Science: Fiction and the Invention of Nineteenth-Century Geology

(Chicago \& London: The University of Chicago Press, 2013), 377 p, ISBN 978-0-226-

07968-4

Throughout the nineteenth century, geological and paleontological discoveries created many sensations. Increasing evidence of a primeval world unsettled beliefs about the origins of the Earth and of mankind. Rewriting the history of the earth strongly impacted not only scientific knowledge but also the economic and cultural life of the nation, as Adelene Buckland's Novel Science: Fiction and the Invention of Nineteenth-Century Geology explains. Geology was not new in the nineteenth century but, Buckland argues, it was "written into existence in the nineteenth century, as much as it was found, discovered, collected, mapped, or modelled" (4). As more and more field geologists roamed the earth, geology changed, involving activities ranging from the collection and classification of specimens to the mapping of the world. The emergence of geology as a scientific discipline did not go unnoticed on the cultural scene, as many Victorian novels depicted characters riveted by geological discoveries or engaging in geological activities, for instance. However, Buckland's study aims less at tracing such representations of geology or geologists in literary texts than at showing how "the principle practices of the geologist was, itself, literary" (13). Therefore proposing a book about "the literary culture of the science" (13), Buckland explains how narratives became a significant tool for geological writers whose writings borrowed literary devices and patterns to express new truths about the world. Thus, instead of looking at literature as a means of promoting geology and popularising geological knowledge, 
Buckland shows how writing was part of the scientific practice. Novel Science is divided into two main parts, the first one dealing with geologists' quest for a specific language far from biblical cosmogony, while the second one looks at the relations between science and literature and examines how Victorian novelists dealt with the question of form which permeated the Victorian period.

2 Part one, "Stories in science", examines the 1802 rewriting and popularisation of James Hutton's Theory of the Earth (1788 and 1795) by John Playfair (Illustrations of the Huttonian Theory of the Earth). The first chapter explains how geologists gradually moved away from Hutton and Playfair's cosmological thinking, choosing instead new forms to tackle the history of the earth, such as those of the novelist Walter Scott. In the second chapter, which looks at the literary culture of the Geological Society gentlemen, Buckland examines the geologists' "imaginative and cultural identification with Scott" (58), explaining the circulation of the image of the knightly geologist. Scott's landscape descriptions of the violence of the geological world informed many geological depictions which drew upon romantic or gothic images. Buckland analyses, for instance, Adam Sedgwick and Roderick Murchison's use of John MacCulloch's Description of the Western Islands of Scotland (1819). The latter, hovering as it did between a romantic and dramatic vision recalling Scott's fictional Highlands and more rational descriptions of the landscape, was rewritten by Sedgwick and Murchison in plot-free descriptions (even if their letters were somewhat different). The popularity of Scott explains why writers would appropriate his style to achieve success, to the extent that he provided a language that became part of geological practice. In Chapter Three, on Charles Lyell's mock epic, Buckland examines the impact that the epic form had on geological writers, following in the footsteps of Ralph O'Connor's study in The Earth on Show: Fossils and the Poetics of Popular Science, 1802-1856 (2007) and Bernard Lightman's Victorian Popularizers of Science: Designing Nature for New Audiences (2007). As geologists, such as Lyell, were looking for a scientific method that allowed speculation and made room for the invisible/unobservable past, the epic continued to associate geology with the classical and literary traditions. The form enabled geologists like Lyell to reconstruct the full story of the earth despite its fragmentary remains. In Chapter Four, Buckland then turns towards the geological map, viewing mapmaking as much as an imaginative layout of the land as a scientific one. She looks at the impact of Emily Brontë's novel, Wuthering Heights (1847) on the geological presentation of the Yorkshire landscape, and explains how the story may have been inspired by a local legend which involved Sedgwick: the story of a contested will in Sedgwick's home village of Dent in the northeast of Yorkshire, for which Sedgwick acted as executor. The links between the forms of the mountains and the forms of language (ancient dialects preserved by the mountains), moreover, could act as evidence of vanished geological forms. Buckland also examines Isabella Banks's novel, Wooers and Winners; or, under the scars; $a$ Yorkshire story (1880), another potential rewriting of the story of Dent which is set in an explicitly geological setting. The protagonist, engrossed in his geological activities, fails to act as a good executor to a will, whilst the plot revolves around the discovery of a cave.

3 Part 2, "Science in Stories", explores textual relationships between canonical Victorian novels and geological writings. It opens with a chapter on Charles Kingsley. Kingsley became a member of the Geological Society in 1863 and corresponded with the leading geologists of the time, from Charles Lyell to Charles Darwin and T. H. Huxley. 
Furthermore, as Buckland contends, his "geological studies gave him a means by which to interrogate his practice as a novelist" (181). Buckland looks at Kingsley's image of the ideal scientist and focuses on Yeast: A Problem (1851), Alton Locke (1850) and Two Years Ago (1857). She arguably revises older analyses of Alton Locke's transformation (seen as a "geological retrospect" more than as an evolutionary narrative) and stresses how Kingsley's novels are framed and structured by geology. In the following chapter, on George Eliot's novels, Buckland looks at The Mill on the Floss (1860) and Daniel Deronda (1876), showing how Eliot systematically provides various explanations for potentially geological phenomena, such as the flood in The Mill, often using the landscape to map out the characters' own place in the world. The symbolical power of the landscape works therefore in tandem with a realistic vision of the world, typifying the extent to which Eliot's scientific knowledge informed her fiction. The last chapter recalls how Charles Dickens was fascinated with natural history and the popular theatrical reconstructions of landscapes, from pantomimes showing volcanic eruptions to panoramas. The variety of shows and exhibitions were reflected in many of Dickens's novels, Buckland shows, examining Dombey and Son (1846), Bleak House (1853) and Our Mutual Friend (1865). For Buckland, Dickens's changing urban worlds and cityscapes must be seen as reflecting visions of, or related to, geological disasters. If the geological references and forms used by Victorian novelists seem to impart authority to their writings, as Buckland suggests, Victorian novelists such as Kingsley and Eliot, who moved in scientific circles, or even Dickens, who liked to popularise the latest scientific discoveries, ultimately served to "suggest dark and disturbing ruptures in the continuous flow of the plot" (275), offering thereby a highly modern shaping of the world and of history. Thoroughly researched, Novel science, mingling as it does explorations of science writings and literary analyses of canonical Victorian novels, is a highly stimulating addition to the increasingly interdisciplinary field of English studies.

\section{INDEX}

Keywords: geology, literature and science, Victorian

Mots-clés: géologie, littérature et science, victorien

\section{AUTHORS}

\section{LAURENCE TALAIRACH-VIELMAS}

Université de Toulouse 2-Jean Jaurès

Professeur

talairac@univ-tlse2.fr 